\title{
Assessment of the warning system against floods on a rural area: the case of the lower Siret River (Romania)
}

\author{
F. Salit ${ }^{1,2}$, L. Zaharia ${ }^{2}$, and G. Beltrando ${ }^{1}$ \\ ${ }^{1}$ Univ. Paris Diderot, Sorbonne Paris Cité, UMR8586 du CNRS (PRODIG), Paris, France \\ ${ }^{2}$ Faculty of Geography, University of Bucharest, Bucharest, Romania \\ Correspondence to: F. Salit (florence.salit@gmail.com) \\ Received: 12 August 2012 - Published in Nat. Hazards Earth Syst. Sci. Discuss.: \\ Revised: 9 December 2012 - Accepted: 15 January 2013 - Published: 15 February 2013
}

\begin{abstract}
The development of non-structural measures such as an early warning system, across the Europe, in flood risk management, requires a better understanding of the public involved and of the territory threatened. This paper aims to conduct an assessment of early warning and information to people with an analysis of the population's behaviour, presented in a form of an event tree. The objective is to understand the strengths and weaknesses of the warning system during a deadly flood in the lower Siret River (Romania) in 2005 and to demonstrate that each warning system has to be adapted to the territory in which it is effective. The behavioural model aims to determine to what extent the warning system can be improved but also to suggest ways to adapt risk education to the study area.
\end{abstract}

\section{Introduction}

During the past years, a significant change in the Romania hazard management system took place due to two major events. First devastating floods and thunderstorms hit Romania in 2005 causing 76 deaths and material damages estimated at 1.7 billion euro (M.M.G.A., 2006). In some regions of the country, these floods have exceeded in terms of magnitude, surface inundated or damage, all events produced in the last half century (Zaharia et al., 2006). In July 2005 a flood hit the lower Valley of the Siret River. It is the most important river in Romania $\left(726 \mathrm{~km}\right.$ in length and $42890 \mathrm{~km}^{2}$ area of the catchment), draining the east of Romanian Carpathians (Fig. 1). The maximum discharge recorded during this flood, at Lungoci gauging station, was $4650 \mathrm{~m}^{3} \mathrm{~s}^{-1}$ (Romanescu and Nistor, 2010), and in some places the water reached a height of 4 meters. It was the biggest discharge recorded at this station since 1955, the year of the beginning of streamflow measurements (the mean annual discharge at Lungoci station is $210 \mathrm{~m}^{3} \mathrm{~s}^{-1}$ ). Twenty-three victims and several million euros of damage have been reported. This historic flood has highlighted the defects of the flood protection system in Romania, including gaps in non-structural measures.

The second event is the integration of Romania in the European Union. Until the 2000s the system of defense against floods in Romania, consisted mainly of structural measures: regularisation of river channels, embankments and dams. It is now recognised that structural flood control alone is not sufficient and does not solve the flood problem (Kundzewicz, 1999; Merz et al., 2010; Bradford et al., 2012). Since the integration of Romania into the European Union, the Romanian Government has introduced new legislation to implement the Water Framework Directive (2000/60/EC) and the Flood Directive (2007/60/EC). Currently a national strategy to fight against floods at short- term and medium-long-term (2011-2030) is in operation (Bousquet, 2008). This strategy has three major aims: to create a better coordination between services for flood control at all levels (i), to redesign and to reorganize the structural measures (ii), and to introduce nonstructural measures such as risk education, warning system or public participation (iii).

The flood warning system intends to inform as soon as possible the population of an imminent threat of a flood and thus reduces the loss of human lives and limits damage. It includes three components (Mileti and Sorensen, 1990): the detection system (collection and analysis of information, flood forecasting), the management system (composed of national and local emergency management officials) and the response 


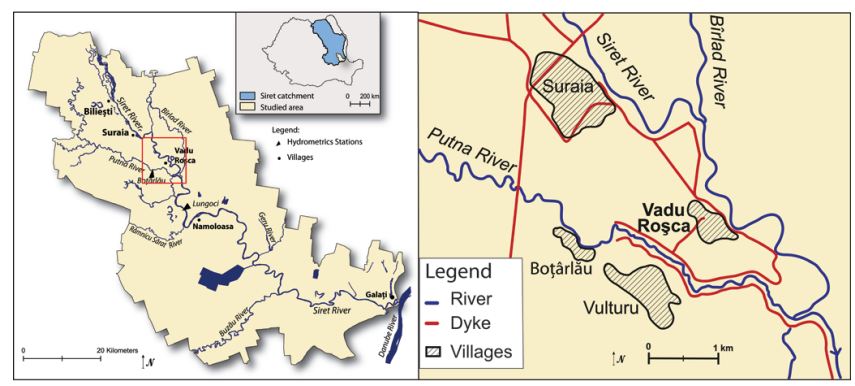

Fig. 1. Localisation of the lower Siret River and of the village of Vadu Roşca.

system (transmission and reception of warnings to the population concerned). This last point appears the most complex because its effectiveness depends on the behaviour of populations. It consists of three phases: ante-event information and education/crisis behaviour/post-event review. Understand how the public responds to the warning is crucial to determine which information should be disseminated to the population in order to increase public trust in authorities and the capacity to act when a flood occurs (Bradford et al., 2012). The behaviour of populations depends essentially on the context in which the flood occurs (Handmer and Ord, 1986; Sorensen and Mileti, 1989; Handmer, 2000). Several criteria can be selected:

- The characteristics of the event (Flash flood/slow flood/territory which has regularly floods).

- When flood occurs (day/night/weekend).

- The socio-economic context (age of populations, resources).

The difficulty is that these systems cannot be universal: the warning system must be adapted to the territory where it is effective. This present study aims to conduct an assessment of early warning and information to people, as it took place on the lower Siret River, in July 2005, with an analysis of the behaviour of the population. The objective is to understand the strengths and weaknesses of the system and thus, determine to what extent it can be improved but also suggest ways to adapt risk education in the study area.

\section{The study area}

The village of Vadu Roşca was chosen for the purpose of the investigation because this village was the most severely affected by flood in July 2005. Vadu Roşca is located on the right bank of the Siret River, upstream of its confluence with the Putna River (Fig. 1). The village is surrounded by a network of earth levees which protects the area from floods of the Siret River (on the right bank) and the Putna River (on the

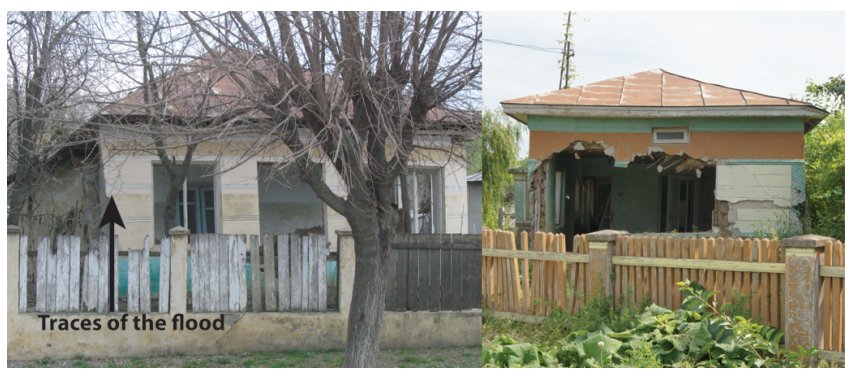

Fig. 2. Example of damaged houses in Vadu Roşca after the flood of July 2005 (pictures: F. Salit, June 2012).

left bank). These structural measures against flood were implemented in 1972, after a major flood in May 1970. During the flood in 2005, this network trapped the water of the Siret River and the Putna River into Vadu Roşca, causing seven deaths (Salit et al., 2012). It is a rural village where the majority of the population lives from agriculture. This village of 1276 inhabitants (2007) is part of the Vulturu commune, located more than $10 \mathrm{~km}$ away, that is to say that Vadu Roşca itself does not have a town hall. Seven years later, traces of the flood are still visible in the streets of the village or on the facades of houses (Fig. 2).

Also the study of the economic and social context is essential in the case of this village. On the one hand, there has been for several years a pronounced rural exodus. On the other hand, many houses belong to Romanians who work abroad. These houses are new and unoccupied for a large part of the year. It is easy to recognise them because they differ from the traditional habitat; they have one floor, in brick or concrete block (not mud) and have raised foundations.

\section{Data and method}

Assessment of the warning system during the flood of July 2005 has two aims: it allows us to identify the faults and qualities of the system and also to trace the information given to the local population so as to bring it more in line with the territory studied. In research on warning systems "context is everything" (Parker et al., 2008). The historical, politicaleconomic, socio-cultural contexts are major elements of the effectiveness of a warning system: either in its conception or in its reception by the population. This is why warning systems adopted in other countries, or even in other catchment areas, are not fully adaptable without local changes. The basic principles can be transposed but adjustments are essential. Three categories of individual factors influence the ability of response to imminent danger and therefore influence the effectiveness of a system (D’Ercole, 1991; Mileti, 1995):

- The nature of social relationships and responsibilities. I. Ruin, in her $\mathrm{PhD}$ thesis in 2007 , shows that women 
with young children tend to take more risks and do not follow the instructions.

- The socio-economic and demographic characteristics.

- The psychological and cultural characteristics.

It is necessary to expose the basic principles of behaviour in crisis situation, as these affect the response to the warning. Five steps have been identified in the behavioural model (Mileti and Sorensen, 1990; Ruin, 2007):

Hearing the warning: it is an essential first step to hear the alert, either by sirens or by other types of alarm.

Understanding the message: even if the message is heard, the content is not always understood. It depends on the socio-cultural context or the experience of the people. And it also depends on the message itself and the preparation of the population to these situations.

Believe: most of the time, people do not believe in the warning and need to verify the information. This need of confirmation has been identified by several authors (Mileti and Sorensen, 1990; Sorensen, 2000; O'Sullivan et al., 2012). Parker et al. (2009) made a comparison of several studies on the behaviour model across Europe. In this comparison he noticed that the need to confirm is one form of behaviour that can be found in all countries. The information to take into account must be received in different forms (plurality of sources). It must be credible and accurate for people to take it.

Personalizing the warning to oneself: a person assesses the risk to oneself according to one's proximity to danger and one's knowledge or personal experience.

Responding by taking protective action: people can act if the warning happens in sufficient time. Also it implies knowledge of the means of protection adapted to the situation.

It is from this behavioural model and from the study of Molinari and Handmer (2011) that the assessment of the warning system in Vadu Roşca was conceived. While the previous authors'goal was to predict the ability of people to act in order to assess the damage caused by flood, the present study described in this paper aims to assess the warning system using Molinari and Handmer's methodology (2011).

An event tree is a graphical representation of an inductive procedure that shows all possible outcomes resulting from an accidental event (Rausand, 2004). Each action is called an event. The analysis of the results is based on a binary logic in which each event takes place or not. The tree itself is adjustable to the situation under investigation as well as to the answers provided (USACE, 1994; Rausand, 2005). The applications of this approach are multiple but it is mainly used in risks analysis (in engineering or in the nuclear industry
(Fullwood and Hall, 1988). But the event tree is especially appropriate in identifying the need of improvement of protection systems and other safety features. The results provide a real basis for work in the assessment of protection systems (Rausand, 2005). A combination of closed and opened questions are adopted. Closed questions and event tree representation allow a rapid visualisation and interpretation of results. Moreover, supplementary open questions allow a more accurate interpretation of the results (Bird et al., 2009). The variable "time" is not included in this method. Thus, this analysis includes the fact that people did not act because the warning was given too late, not because they were incapable of action. The survey questions and the choice of interpretation are presented below:

1. Were you aware of the approach of the flood? (Warning)

The people were aware of the alert if they were warned at least two hours before the start of the flood. For example if they knew that the water came in when their houses were flooded, the answer at the question is no. If the answer to the first question is no, the remaining answers are negative, and it may take into account only the last question on possible actions.

2. Was it an official warning? (Official)

The warning was considered to have been official if people were warned by the mayor or town hall employee, by sirens or by the police. If this was not the case, they have to specify the source. To this question multiple answers were suggested (television, friends or family) to facilitate the autonomous completion of the questionnaires.

3. Did you feel concerned by the warning? (Trust)

The language and vocabulary were adapted to this specific population for the translation of this question in Romanian. Literally the question was: did you understand that the warning concerned you or your house? (The word gospodărie in Romanian has no precise equivalent: it refers as much to movable property as the home or family).

4. Did you check the information? (Confirmation)

More accurately, in romanian: did you check whether the information was correct?

5. Did you take action? (Act)

This time it was decided not to specify options in the subsidiary question. Interviewees might have felt guilty or ashamed of not having taken certain measures. Thus 


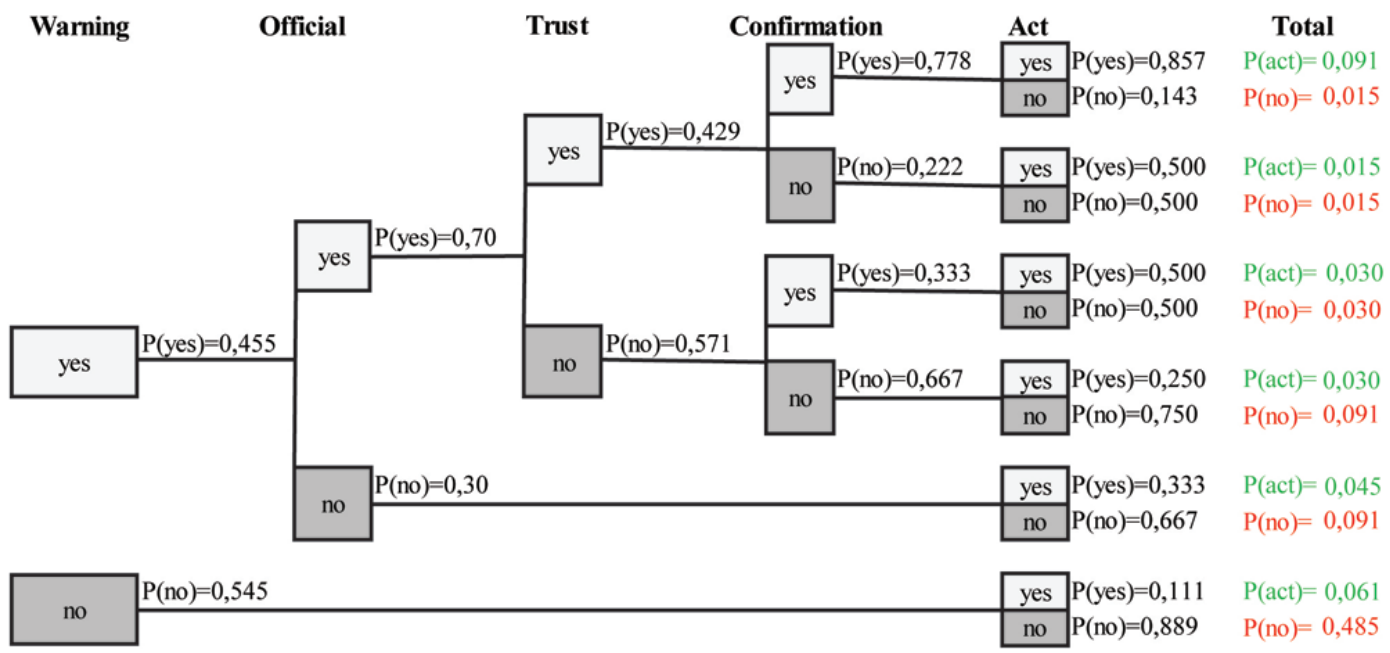

Fig. 3. Results of the 66 questionnaires.

during the interpretation of the results, to flee or to climb on the roof were not considered as a measure of protection against flood. However if the evacuation concerned other persons or goods (children, animals, important papers) the answer is considered as a positive response.

This survey uses three approaches: (i) in order to test the questionnaires and to adjust the interpretation of results based on people's responses, the interviews were conduct first, in the streets of Vadu Roşca. 34 people were interviewed. In fact there were more, but the couples or family members were met together (the number of interviewees may at least doubled). One questionnaire was completed per household in case of individual answers were similar or influenced by each other. (ii) To reach a wider audience and especially people who work during the day, the questionnaires were submitted to teachers of history and geography at the local school. This method gave a formal and official character to the process. Thus not only parents, but grandparents too, could answer. In addition, teachers were able to validate the questionnaires; they are in daily contact with the population and could assess the feasibility of the approach. 24 questionnaires were collected: teachers have 30 students living in Vadu Roşca, including many of the same family; the number of questionnaires was consistent. (iii) Finally displaced persons after the flood were interviewed: 147 houses were built in the nearby village (named Vulturu) for the affected families of Vadu Roşca. Eight people of this area were questioned. A total of 66 questionnaires were analysed.

\section{Results}

As most of the young people and adults (mainly men) are left to work abroad, the current population in Vadu Roşca and Vulturu villages consists of elders and children. Under these conditions, the majority of those surveyed is over $50 \mathrm{yr}$
Table 1. Profile of respondents.

\begin{tabular}{lrrrrr}
\hline Gender & Age & 15-29 & 30-59 & 60 and more & Total \\
\hline Male & 2 & 15 & 10 & 27 \\
Female & 4 & 19 & 16 & 39 \\
\hline Total & 6 & 34 & 26 & 66 \\
\hline
\end{tabular}

(Table 1) and is retired or unoccupied (although they typically pursue an agricultural activity). Many were strongly marked by the flood; they acted as if the event had occurred the previous day. Everyone remembered the event. The conversations were sometimes painful, because some had lost relatives or property in the flood.

The results are summarised in Fig. 3. Results highlight that:

- Only $45.5 \%$ of the 66 people questioned, were aware of the warning regardless of whether it was official $(70 \%)$ or unofficial $(30 \%)$. Thus, only $31.8 \%$ of people questioned were aware of the official warning. This rate is too low to consider that the official warning was efficient.

- Among those who received an official warning, 57\% did not trust it or not feel concerned by it. The result is paradoxical: only those who understood they had to be concerned by the warning felt the need to check information $(77 \%$ of people who had confidence in the official warning sought confirmation).

- By adding the probability of action for each possible branch it is found that $27 \%$ only acted, of whom many received warnings too late or only understood what was happening when the water entered their homes. 


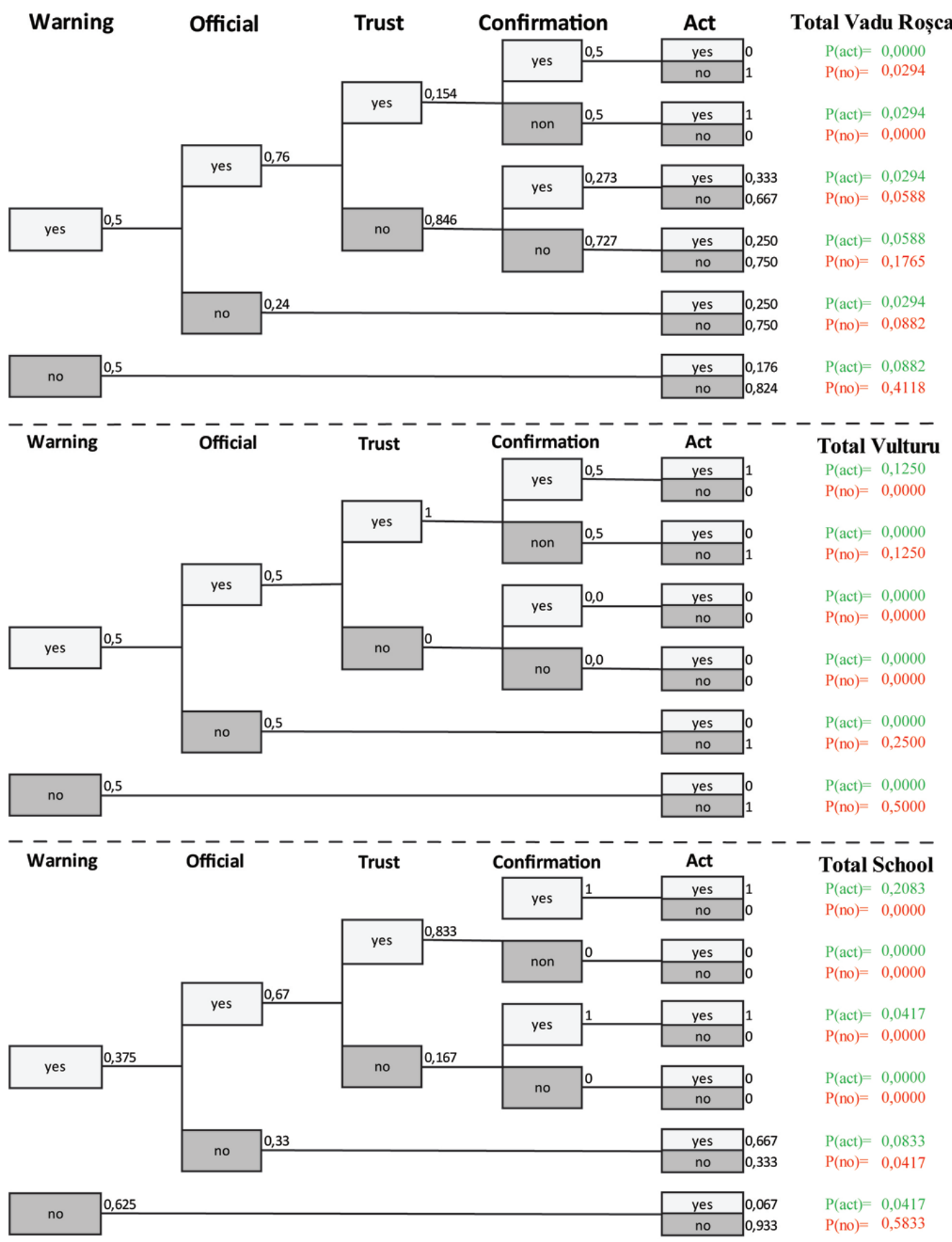

Fig. 4. Detailed results of the questionnaires in Vadu Roşca, Vulturu and at school.

- Less than half of the people warned acted (46\%) but about $52 \%$ of people took some kind of action after the official warning. They tried, in most cases, to shelter animals and protect important papers.

- There were few differences between the various sources or methods of questionnaires (Fig. 4). $50 \%$ to $62 \%$ of respondents received no warning. Among those who received a warning, $50 \%$ to $76 \%$ received it by an official way. The results were similar, except on one point: in the responses from the school, people had confidence in the alert given by the town Hall. Perhaps this was due to the source of the investigation: the school was considered here as the investigator, an official institution and also the respondents were perhaps not inclined to criticize the town hall. Whereas in Vadu Roşca about $84 \%$ 
of people who received an official warning had no confidence on this one.

\section{Discussion}

\subsection{An inefficient warning system}

Less than half of the population received a warning the day before the flood (although two were warned several days before). Two facts can explain this rate. First the warning itself was given from door to door, and not everyone could be reached. Then the local authorities hesitated to warn the inhabitants. For several days, the Siret River was placed under surveillance: the town Hall inspected dykes in order to assess their state. But water arrived first from the Putna River, a factor not expected by the authorities. The water came from upstream from the Putna River; water from the Siret River then flowed through the village. These circumstances weakened the warning messages, as the initial threat did not come from the river nearest the village but located several kilometers away. The first principle of warning system requires that the warning must be clear (USACE, 1994). But in this case the lack of knowledge of the vulnerability of this area conducted to a confuse message. The extent of the phenomenon was widely underestimated by the authorities and by the inhabitants themselves: they attempted to have less than $50 \mathrm{~cm}$ of water in their houses. $54.5 \%$ of population questioned were warned in an informal way. In most cases they were warned by their family. Longer interviews with victims were conducted in various surveys, in which specific information channels emerge. Relatives living upstream on the river came to warn the family members living downstream. These elements highlighted the role of unofficial warning. These networks are not easily quantifiable, and studies show the problems of assessing their effectiveness (Parker and Handmer, 1998). One can retain several elements: the role of the collective memory is undeniable. On the one hand, people's experience lead them to develop reflexes against the warning, but on the other hand, people who have experienced a flood tend to underestimate the danger (Gardner and Stern, 1996; Brilly and Polic, 2005).

\subsection{The population experience}

The majority of respondents, as mentioned before, has more than $50 \mathrm{yr}$ and had always lived in this village. During the various interviews, they all spoke about flooding of the Siret River before 1970. The floods were frequent, once or twice a year, but they were slow, of low-intensity, with never more than $50 \mathrm{~cm}$ of water in the village. Since the major flood in May 1970, embankment and regularisation of the river changed flood patterns. Two elements came into play: dykes led to the feeling that the flood danger was over, or else flooding, as a recurring phenomenon, has been forgotten. Since 1970, no floods of high amplitude have been recorded,

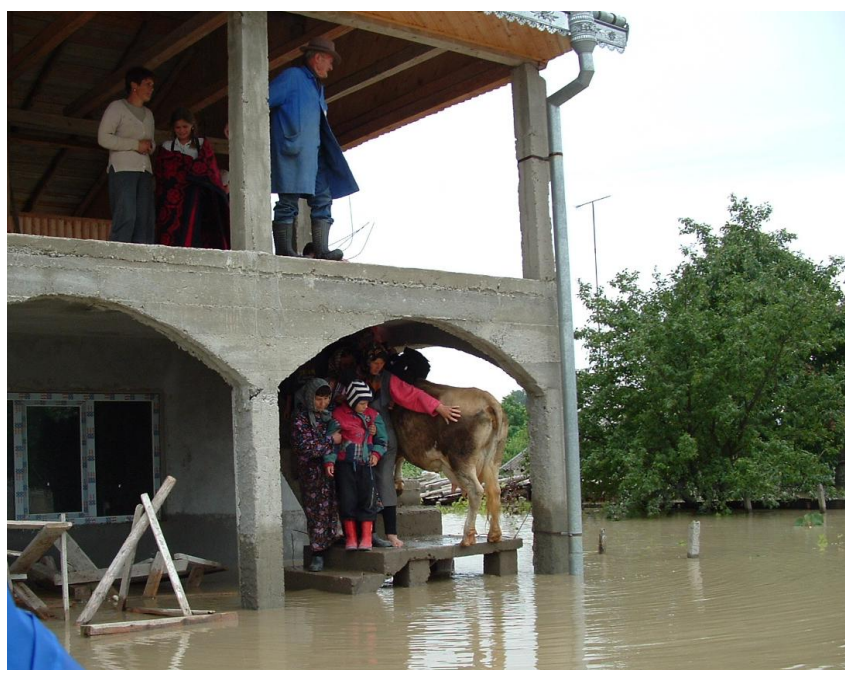

Fig. 5. Inhabitants saving a cow in Vadu Roşca during the flood of July 2005 (Picture: Administraţia Naţională “Apele Române”).

corroborating the popular sentiment. Moreover, for the people, if there is a flood it will be a flood of low intensity just like before. Changes in the dynamics of the Siret River were not taken into account. This experience of the river, this "popular wisdom" (Parker and Handmer, 1998) strongly influenced the behaviour against the warning of 2005. They relied on their old knowledge of the river, without taking into account the extent of the changes made since the 1970s.

\subsection{The role of the animals}

This question may seem secondary, but it appears from various interviews that animals play of major role in the behaviour of people. Some studies investigate the role of animals, pets most of the time. People are able to take risks to save their cat or dog (Wilson, 2006). But the situation in Vadu Roşca does not concern pets. Each household has few animals, a cow, a pig and some poultry. They are not necessarily farmers; these animals are kept for subsistence purposes or else out of tradition. Beyond the affection they attract, they are also a source of income or an aid to self-sufficiency. In every interview, the population mentioned their animals: some barely had time to remove them (Fig. 3), others were injured while trying to save them, and others wept when telling us how they lost their beast. People were willing to risk their lives to save their animals and, in more than $60 \%$ of cases, it was their first act once they received the flood warning. This factor has to be built into the information given to the population. It highlights the need to think ahead about a possible shelter for these animals, or at least take advice on what to do. 


\subsection{Little unsolicited media}

Several studies demonstrate the need for people to check the information and to seek confirmation from the media (Parker et al., 2009). $40 \%$ of respondents in Molinari and Handmer surveys (2011) in Australia sought confirmation of the flood on the radio or on television. In France, the bulk of information to the public in the Vigicrue system is broadcast on the media: radio, television and, increasingly, the internet. A colour code and advice on behavior have been developed and disseminated on weather or information channels. A similar system exists in Romania in the form of a hydrological warning, initiated by ANAR (National Administration of Romanian Water) and accompanied by a map and a description of the basins or sub-basins concerned. On reading the results of the questionnaires, only two people sought confirmation in the media. The population lives primarily outside in the spring or summer and does not automatically refer to the media as an urban population habitually does (Llasat et al., 2009). Thus an alert system in which the media could play a central informative role is less easily adaptable to this type of population. Other approaches should be introduced, like sirens or church-bells, as requested by the population itself.

\section{Conclusions}

The warning system is an essential component of nonstructural measures in the fight against floods. The event tree model is a tool to assess the warning system effectiveness and to determine each element which affects people's behaviour. The results of the study show that the warning system, during the flood of July 2005 on the lower Siret River, had weaknesses that led to many casualties. The people were warned too late to act and when they were warned, they did not trust the warning. There are many factors on this behaviour, including the experience of earlier floods. The questionnaires suggest ways to improve information to the people, including the introduction of advice behavior in crisis situations. Having good preparation and reflexes before an event, is crucial in limiting damage during a flood.

The warning system has undergone improvements since 2005 in Vadu Roşca and the whole commune of Vulturu: sirens have been installed, a local committee of emergency has been created, but these have not been tested during a flood and people are not really aware of these changes.

Involvement of the public in the implementation of a defense strategy against flood is an essential element of the success of an integrated flood risk management but this paper shows that there is a gap between population and authorities. The application of this method to other villages or after new events and the collaboration with local flood management authorities will improve the warning system effectiveness in the lower Siret Valley.
Acknowledgements. This study was supported by the EU EGIDE BRÂNCUŞI - Campus France - program Système hydrogéomorphologique et risques associés: impacts et aménagement territorial (2011-12).

Edited by: L. Ferraris

Reviewed by: two anonymous referees

\section{References}

Bird, D. K.: The use of questionnaires for acquiring information on public perception of natural hazards and risk mitigation - a review of current knowledge and practice, Nat. Hazards Earth Syst. Sci., 9, 1307-1325, doi:10.5194/nhess-9-1307-2009, 2009.

Bousquet, H.: Synthesis of the national medium- and long-term flood risk management strategy, 27 pp., 2008.

Bradford, R. A., O'Sullivan, J. J., van der Craats, I. M., Krywkow, J., Rotko, P., Aaltonen, J., Bonaiuto, M., De Dominicis, S., Waylen, K., and Schelfaut, K.: Risk perception - issues for flood management in Europe, Nat. Hazards Earth Syst. Sci., 12, 2299-2309, doi:10.5194/nhess-12-2299-2012, 2012.

Brilly, M. and Polic, M.: Public perception of flood risks, flood forecasting and mitigation, Nat. Hazards Earth Syst. Sci., 5, 345-355, doi:10.5194/nhess-5-345-2005, 2005.

D'Ercole, R.: La vulnérabilité des populations face au risque volcanique. Le cas de la région du volcan Cotopaxi (Equateur), thèse de doctorat, Université Joseph Fourier, Grenoble, 460 pp., 1991.

Fullwood, R. R. and Hall, R. E.: Probabilistic risk assessment in the nuclear industry, 1st Edn., Pergamon Press, New York, 318 pp., 1988.

Gardner, G. T. and Stern, P. C.: Environmental problems and human behavior, Boston, Allyn and Bacon, 169 pp., 1996.

Handmer, J. W.: Are flood warnings futile? Risk communication in emergencies, Australias J. Disaster Trauma Stud., 2000, 2, available at: http://www.massey.ac.nz/ trauma/issues/2000-2/ handmer.htm, 2000.

Handmer, J. W. and Ord, K. D.: Flood warning and response, in: Flood warning in Australia, Canberra: Centre for Resource and Environmental Studies, edited by: Smith, D. I. and Handmer, J. W., 1986, 235-257, 1986.

Kundzewicz, Z. W.: Flood protection sustainability issues, Hydrol. Sci. J., 44, 559-571, 1999.

Llasat, M. C., Llasat-Botija, M., and Lṕpez, L.: A press database on natural risks and its application in the study of floods in Northeastern Spain, Nat. Hazards Earth Syst. Sci., 9, 2049-2061, doi:10.5194/nhess-9-2049-2009, 2009.

Merz, B., Hall, J., Disse, M., and Schumann, A.: Fluvial flood risk management in a changing world, Nat. Hazards Earth Syst. Sci., 10, 509-527, doi:10.5194/nhess-10-509-2010, 2010.

Mileti, D.: Factors related to flood warning response, US-Italy research Workshop on the hydrometeorology impacts, and management of extreme floods, Perugia, Italy, Novembre 1995, 17 pp., 1995.

Mileti, D. S. and Sorensen, J. H.: Communication of Emergency Public Warnings: A Social Science Perspective and State-of-theArt Assessment, Prepared for the Federal Emergency Management Agency, Washington, DC Prepared by the Oak Ridge National Laboratory, Oak Ridge, Tennessee, USA, 166 pp., 1990. 
Ministerul Mediului şi Gospodăririi Apelor (M.M.G.A.): Raport privind efectele inundaţiilor şi fenomenelor meteorologice periculoase produse în anul 2005, Bucureşti, 40 pp., 2006.

Molinari, D. and Handmer, J.: A behavioural model for quantifying flood warning effectiveness, J. Flood Risk Manage., 4, 23-32, 2011.

O’Sullivan, J. J., Bradford, R. A., Bonaiuto, M., De Dominicis, S., Rotko, P., Aaltonen, J., Waylen, K., and Langan, S. J.: Enhancing flood resilience through improved risk communications, Nat. Hazards Earth Syst. Sci., 12, 2271-2282, doi:10.5194/nhess-122271-2012, 2012.

Parker, D. J. and Handmer, J.: The role of the unofficial flood warning system, J. Contingen. Crisis Manage., 6, 45-60, 1998.

Parker, D. J., Priest, S., Schildt, A., and Handmer, J.: Modelling the Damage Reducing Effects of Flood Warnings, FLOODsite Final Report T10-07-12, Flood Hazard Research Centre, Middlesex university, London, 2008.

Parker, D. J., Priest, S. J., and Tapsell, S. M.: Understanding and enhancing the public's behavioral response to flood warning information, Meteorol. Appl., 16, 103-114, 2009.

Rausand, M.: Presentation of a book chapter: System analysis, Event tree analysis, in: System reliability theory, 2nd Edn., Wiley, 28 pp., 2004.

Romanescu, G. and Nistor, I.: The effects of July 2005 catastrophic inundations in the Siret River's Lower Watershed, Romania, Nat. Hazards, 57, 345-368, 2010.
Ruin, I.: Conduite à contre-courant. Les pratiques de mobilité dans le Gard: facteur de vulnérabilité aux crues rapides, Thèse de doctorat, Université de Grenoble 1-Joseph Fourier, 362 pp., 2007.

Salit, F., Beltrando, G., and Zaharia, L.: The impact of the July 2005 flood to river Management: study case of the Lower Siret River (Romania), in: European Continental Hydrosystems under Changing Water Policy, edited by: Arnaud-Fassetta, G., Masson, E., and Reynard, E., Friedrich Pfeil Verlag, München, 273-279, 2013.

Sorensen, J. H.: Hazard warning systems: review of 20 years of progress, Nat. Hazards Rev., 1, 119-125, 2000.

Sorensen, J. H. and Mileti, D.: Warning and evacuation: answering some basic questions, Ind. Crisis Q., 2, 195-210, 1989.

USACE, US Army Corps of Engineering: Framework for estimating national economic development benefits and other beneficial effects of flood warning and preparedness systems, IWR Report 94-R-3, 114 pp., 1994.

Wilson, T.: Les risques de blessures et de décès par imprudence lors des inondations, Responsabilité et Environnement no 43, juillet 2006, 57-63, 2006.

Zaharia, L., Beltrando, G., Nedelcu, G., Boroneanţ, C., and IoanaToroimac, G.: Les inondations de 2005 en Roumanie, Actes du XIX eme Colloque International de Climatologie, Epernay (France), 557-562, 2006. 